\title{
SCREENING OF EXTRACTION METHOD FOR ALKALOID ENRICHMENT OF PEPEROMIA PELLUCIDA (L.) KUNTH
}

\author{
ISLAMUDIN AHMAD ${ }^{1,2 *}$, RISSYELLY ${ }^{2}$, AGUS KURNIAWAN $^{3}$, ABDUL MUN'IM $^{2 *}$ \\ ${ }^{1}$ Department of Pharmaceutical Sciences, Faculty of Pharmacy, Mulawarman University, Samarinda, East Kalimantan, Indonesia. \\ ${ }^{2}$ Department of Pharmaceutical Sciences, Faculty of Pharmacy, Universitas Indonesia, Depok 16424 West Java, Indonesia. ${ }^{3}$ Department of \\ Pharmacy, Faculty of Medicine and Health, Gunadharma University, Depok, West Java, Indonesia. \\ Email: islamudinahmad@yahoo.com/munimabdoel@gmail.com
}

Received: 02 March 2017, Revised and Accepted: 13 April 2017

\section{ABSTRACT}

Objective: The aims of this study were to investigate the effect of extraction method modification of Peperomia pellucida (L.) Kunth herbs for alkaloid enrichment and thin layer chromatography (TLC) profile.

Methods: The dried herbs were extracted with six different methods (including; method A, B, C, D, and E). The obtained extract solution was evaporated and was analyzed. Alkaloid content identified using Dragendorff spray reagent. The gravimetric method was used to determine of total alkaloid, and TLC profile was analyzed using a densitometer at a wavelength of $254 \mathrm{~nm}$ and $366 \mathrm{~nm}$.

Results: The results showed a difference from all modification of extraction method for alkaloid enrichment and their TLC profile. The use of eluent dichloromethane (DCM):methanol (95:5) was potential for isolation of the compound. From whole extraction methods, only one that tested positive for alkaloids was method A. Total alkaloids in DCM fraction amounted to $29.59 \mathrm{mg} / \mathrm{g}$ piperine.

Conclusion: Based on the above results, method A can be applied for isolation of alkaloid compound from this herb.

Keywords: Peperomia pellucida (L.) Kunth, Extraction method, Alkaloid enrichment, Thin layer chromatography profile.

(C) 2017 The Authors. Published by Innovare Academic Sciences Pvt Ltd. This is an open access article under the CC BY license (http://creativecommons. org/licenses/by/4. 0/) DOI: http://dx.doi.org/10.22159/ajpcr.2017.v10i7.18246

\section{INTRODUCTION}

Peperomia pellucida (L.) Kunth is herbaceous of Piperaceae family. It can be found in places such as under the wall, on the ground side of the road, and under the tree. This herb traditionally used to treat a headache accompanied by fever, abdominal pain, hypertension, and diabetes mellitus [1,2]. The use as diabetes mellitus has demonstrated in the previous studies [3]. The ethanol extract of $P$. pellucida herbs has proven to have gout activity in mice and rats [4]. Moreover, this herb also has anti-inflammatory, analgesic, antipyretic activity [3,5], and angiotensin converting enzyme inhibitors $[6,7]$.

P. pellucida herb contains flavonoids, phenols, terpenes, and essential oil $[8,9]$. Some of the new compounds have been isolated, namely, two secolignan, two tetrahydrofurans, dihydronaftalenon methoxilation [10], pelucidin A, dilapiole [11], and chromene [12]. Many studies reported that the herb contains alkaloids [13-18]. However, no data from studies that reported the results of the isolation and characterization of alkaloid compounds found in P. pellucida herbs. Therefore, we were interested in extraction and isolation of alkaloids from this herb. Isolation of alkaloids is not easy because it desperately needed a special method for separating alkaloids from plants in contrast to the isolation of the compounds exist in general. Based on the above reason, we carried out a study to find the optimal extraction method which can be applied for alkaloid enrichment in the resulting extract.

\section{MATERIALS AND METHODS}

Plant materials

P. pellucida herbs were collected from Bogor Botanical Garden, Indonesian Institute of Sciences. The voucher specimens identified at the Herbarium Bogoriense, Bogor, West Java, Indonesia and were deposited at Pharmacognosy-Phytochemistry Laboratory, Universitas Indonesia, West Java, Indonesia.
Chemical material and general equipment

The used chemical in this study included N-hexane, dichloromethane (DCM), methanol $(\mathrm{MeOH})$, chloroform $\left(\mathrm{CHCl}_{3}\right)$. Toluene (analytical grade), acetone (analytical grade), ethanol (analytical grade), ethyl acetate (analytical grade) were purchased from Smart Lab Indonesia. $\mathrm{CHCl}_{3}$ (analytical grade), 25\% $\mathrm{NH}_{4} \mathrm{OH}$ (analytical grade), and $\mathrm{HCl}$ (analytical grade), sodium carbonate, disodium sulfide, thiourea were purchased from Merck, Germany, TLC Silica Gel $60 \mathrm{~F}_{254}$ (Merck, Germany). Moreover, the used equipment included chamber and densitometer Camaq Wincat 3 TLC Scanner (Camaq, Switzerland); a rotary evaporator (Buchi, Germany); spectrophotometer UV-VIS (Thermo Scientific, USA); vortex mixer (WiseMix ${ }^{\circledR}$ VM-100, Korea), as well as equipment for maceration and soxhlet extraction.

\section{Extraction methods}

Method A

Extraction with maceration using acid-base extraction method reported by Tiong et al. [19], with modification. Dried P. pellucida herbs were macerated with n-hexane for 3 days at room temperature, and the process was repeated twice. After removal of solvent, the residue was firstly soaked with $25 \%$ ammonia for an hour, followed by soaking with DCM. The DCM extract (DE) obtained after filtered and dried under reduced pressure. DE was subjected to acid-base extraction using $5 \%$ hydrochloric acid and $25 \%$ ammonia solution to obtain of crude alkaloid.

\section{Method B}

Dried $P$. pellucida herbs were extracted with Soxhlet using $\mathrm{MeOH}$ $\left(\mathrm{CH}_{3} \mathrm{OH}\right)$ several times; $\mathrm{MeOH}$ extract (ME) solution was evaporated using rotary vacuum evaporator. ME produced and applied for the next fractionation process. The $\mathrm{ME}$ was dissolved in $0.5 \mathrm{M} \mathrm{HCl}$ then was put into a separatory funnel and washed with $\mathrm{CH}_{2} \mathrm{Cl}_{2}$. The $\mathrm{CH}_{2} \mathrm{Cl}_{2}$ layer 
was separated (fraction 1) and then acid layer washed with $\mathrm{CH}_{2} \mathrm{Cl}_{2}$ and basified to $\mathrm{pH} 9$ using $25 \%$ ammonia solution. Obtained $\mathrm{CH}_{2} \mathrm{Cl}_{2}$ layer was separated (fraction 2) and then alkali layer was washed with $\mathrm{CH}_{2} \mathrm{Cl}_{2}$ and basified to $\mathrm{pH} 11$ (25\% ammonia) to give $\mathrm{CH}_{2} \mathrm{Cl}_{2}$ layer (fraction 3 ) and alkali layer. Fraction 1, 2, 3 contain alkaloid (if any).

\section{Method C}

Extraction with maceration using acid-base extraction method by Lebrini et al., 2011 [20] with modification. Briefly, dried P. pellucida herbs were treated with alkaline solutions $\left(5 \% \mathrm{NH}_{4} \mathrm{OH}\right)$. The alkalized raw material was extracted with DCM $(3 \times 200 \mathrm{~mL})$. Filtration collected the extract and the combined DCM fractions were washed with water $(2 \times 200 \mathrm{~mL})$. Then, the organic layer was extracted three times with diluted $\mathrm{HCl}$. The combined aqueous fractions were washed with DCM $(3 \times 80 \mathrm{~mL})$, and the $\mathrm{pH}$ of the aqueous solution adjusted to 9 with $25 \% \mathrm{NH}_{4} \mathrm{OH}$. This aqueous layer was extracted with DCM $(3 \times 100 \mathrm{~mL})$, and the combined organic layers were washed with distilled water $(2 \times 100 \mathrm{~mL})$, dried over $\mathrm{Na}_{2} \mathrm{SO}_{4}$, and collected by filtration. The solvent was removed under reduced pressure to give the alkaloid (if any).

\section{Method D}

Extraction with reflux using dilute acid solution. The dried P. pellucida herbs were refluxed using $0.5 \mathrm{~N} \mathrm{HCl}$ and heated for a few minutes. Moreover, then was filtered and separated from solution and residue. The acid solution was extracted with DCM for three times. Formed two layers, namely, DCM layer (1) and acid layer (2). DCM layer (1) basified using 1-2\% $\mathrm{NH}_{4} \mathrm{OH}$, then formed two layers is a layer of DCM (fraction 1) and the base layer. The base layer was basified again with $25 \% \mathrm{NH}_{4} \mathrm{OH}$ and extracted with DCM and DCM layer was separated (fraction 2). The next layer is the acid (2) was added ammonia solution to $\mathrm{pH} 9-10$ and extracted with DCM. DCM layer was basified with $\mathrm{NaOH}$ and then separated again. DCM layers were dried (fraction 3).

\section{Method E}

Acid-base extraction method using Wagner method [21] with slight modification. Briefly, dried P. pellucida herbs were shaken for 15 minutes with $0.1 \mathrm{~N}$ sulfuric acid and then filtered. The filter was washed with $0.1 \mathrm{~N}$ sulfuric acid; concentrated ammonia then added. The mixture shakes with two portions of diethyl ether. The ether was dried over anhydrous $\mathrm{NaSO}_{4}$, filtered and evaporated to dryness and the residue was dissolved in $\mathrm{MeOH}$.

\section{Determination of thin layer chromatography (TLC) profile}

TLC profile determination was conducted by TLC method using TLC plates as the stationary phase and eluent comparison based on the level of polarity as the mobile phase. TLC profile analysis using a densitometer (Camag Wincat TLC Scanner 3) at a wavelength of $254 \mathrm{~nm}$ and $366 \mathrm{~nm}[22,23]$.

\section{Alkaloid identification}

Identification of alkaloid was performed using the Dragendorff spray reagent. Reagent sprayed on the TLC plate which eluted with an appropriate eluent. Reaction tested positive if the color changes to orange-brown on particular spots $[24,25]$.

\section{Calculation of total alkaloids}

The method was used to calculating the total alkaloid extract refer to a Sreevidya and Mehrotra, 2003 [26] method where using the gravimetric method. The principle of the gravimetric method is the formation of precipitate complexes by reagents that react with alkaloid like Dragendorff reagent. Theses precipitate measured with visible light $435 \mathrm{~nm}$ using spectrophotometry.

\section{RESULTS AND DISCUSSION}

Alkaloids are secondary metabolites whose presence in a plant species is very limited and has limited distinguish feature of each plant. Alkaloids extraction is not easy when it needs special methods to attract alkaloids contained in plants. Based on several studies has reported that contains alkaloid [13-18], but, until now, there have been no reported studies related to the isolation and characterization of alkaloid compounds contained in the plant. In this research, the effect of an extraction method for enrichment and their TLC profile. However, not only the class of alkaloids but also all the compounds contained in extracts of this plant are based on profiles TLC. The objective of our study was to determine the effect of extraction methods for the alkaloid enrichment and its TLC profile.

In this study, the extraction was conducted using five kinds of modification of the extraction method using $100 \mathrm{~g}$ of dried samples (each method). From the extraction method was obtained for each extract namely, method A resulted in $24.63 \mathrm{~g}$, method B was obtained three fractions namely fraction extract B1 (20.14 g), B2 (18.86 g) and B3 (10.05 g), method C was $23.17 \mathrm{~g}$, method D was obtained two fractions of each extract D1 (12.34 g), D2 (7.05 g), and method E (extract E) was $5.32 \mathrm{~g}$. The use and modification of the method are carried out with the aim to minimize chlorophyll compounds contained in these desired plants extract.

\section{Determination profile TLC}

TLC profile determination was conducted using the TLC plate that has activated. The eluent used three kinds, such as the combination of DCM: $\mathrm{MeOH}$ (95:5), toluene: ethyl acetate (70:30), and toluene: acetone:ethanol:25\% ammonia (20:20:3:1). Each combination of the eluent was analyzed using a densitometer at a wavelength of $254 \mathrm{~nm}$ and $366 \mathrm{~nm}$ (Fig. 1).

As can be seen in Table 1 showed, the deployment of the highest number of spots, namely, the method A and C was 22 spots; the method D (two fractions) was 22 (D1) and 18 (D2) spots; the method B (three fractions) was total spots of 19 (B1), 15 (B2), and 17 (B3); the method $\mathrm{E}$ was 15 spots, whereas for the control of the Piperine (three spots) and spot spread use than any other comparison eluent.

In Table 2 shows, the deployment of the highest number of spots was 16 spots (method C), 15 spots (method B, fraction 1 and 2), 14 spots $(\operatorname{method} \mathrm{A}), 13$ spots $(\operatorname{method} \mathrm{E}), 12$ spots $(\operatorname{method} \mathrm{D}$, fraction 1$)$, 8 spots (method B, fraction 3 ), and 7 spots (method D, fraction 2), respectively, whereas for the control of piperine (three spots).

In Table 3 shows, the spread of the highest number of spots was method D (fraction 1; 14 spots), method B and A (10 spots), and methods C and E (8 spots), while the control of Piperine (three spots). It shows that all the modifications methods obtained TLC profile different based on the difference polarity of the compound were attracted to each kind of eluent combinations. Moreover, also based on the Rf value for each combination of eluent used to show that the combined use of eluent DCM: $\mathrm{MeOH}$ (95:5) (Table 1) have the potential for further study especially isolation of the target compound because the separation spots were obtained the best spread.

\section{Alkaloids identification}

P. pellucida contains alkaloids using reagents Dragendorff to see the results formed of brownish orange precipitation. While the identification of alkaloids in this study was performed using reagents Dragendorff spray that sprayed on the TLC spot outcome from each extract. However, the five methods were only one who tested positive for alkaloids namely method A than the control positive of piperine (Fig. 2). The results do not ensure their continued with improvements in the identification and enrichment of alkaloids from this plant but it may alsWo be influenced by place to grow plants that affected the content of alkaloids or the extraction method used has not maximized. 


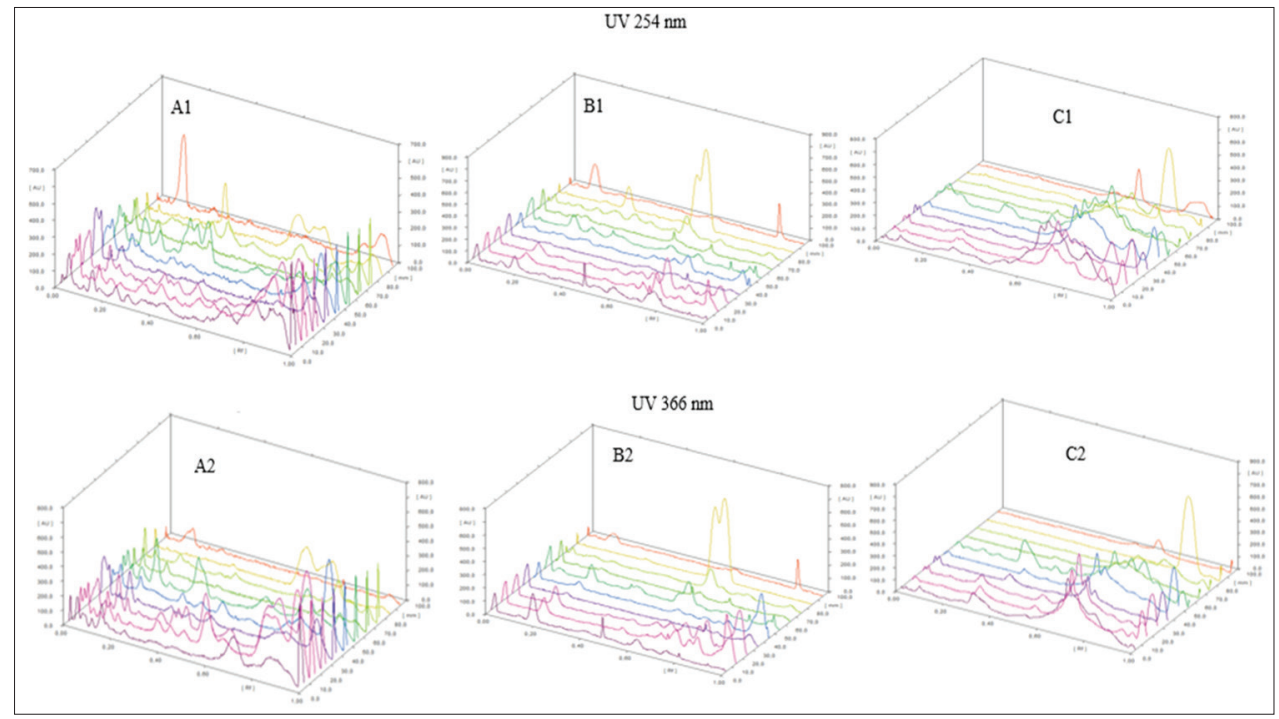

Fig. 1: Thin layer chromatography (TLC) profile using densitometry TLC scanner, (A) using dichloromethane:methanol eluent (95:5), (B) using toluene:ethyl acetate (7:3), (C) using toluene:acetone:ethanol:25\% ammonia (20:20:3:1)

Table 1: TLC profiles using dichloromethane:methanol eluent (95:5)

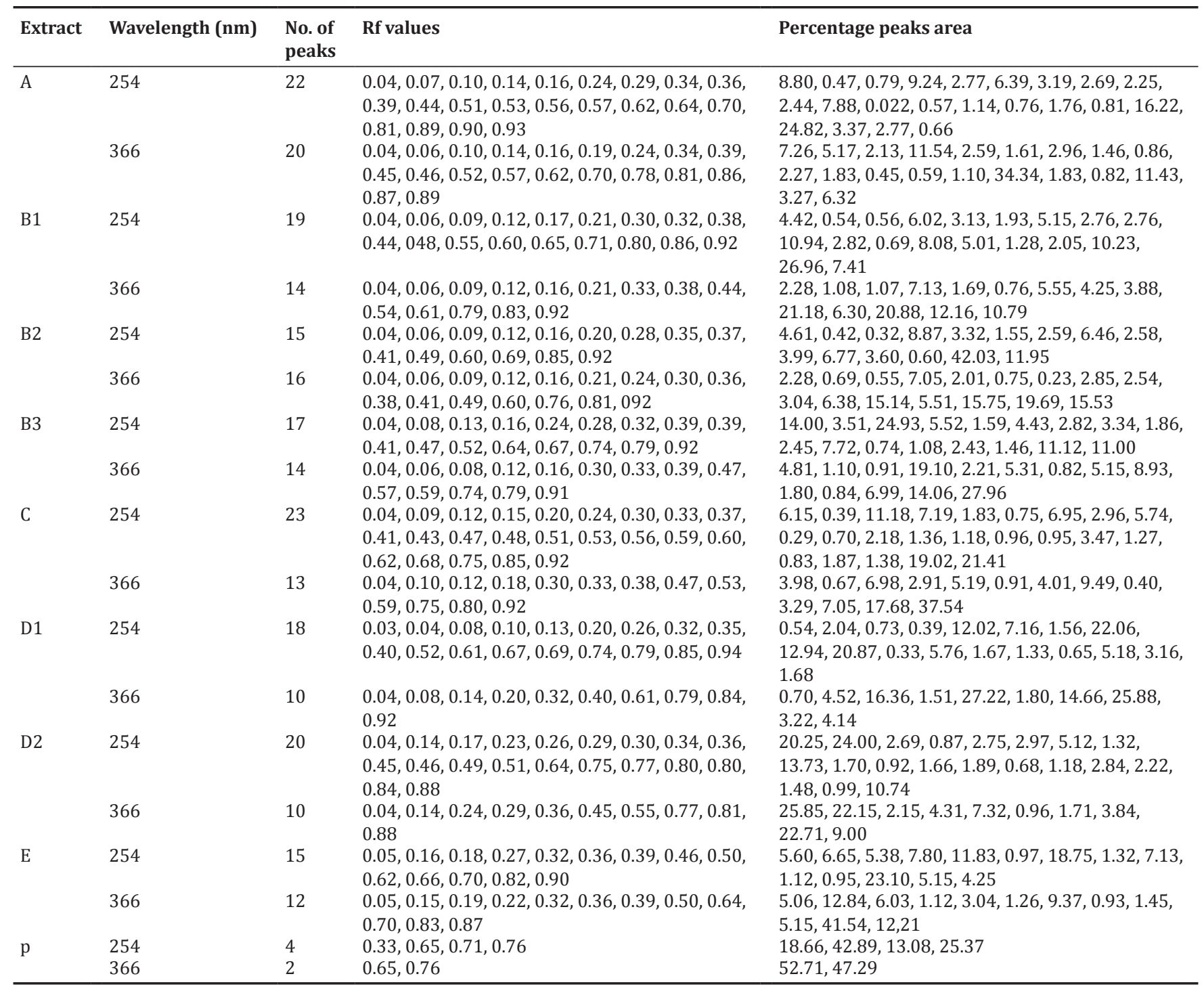

A - A method, B - B methods (3 fraction), C - C method, D - D methods (2 fraction), E - E method, piperine (control), (254 and 366 ) wavelength at 254 and 366 nm. TLC: Thin layer chromatography 
Table 2: TLC profiles using toluene:ethyl acetate eluent (7:3)

\begin{tabular}{|c|c|c|c|c|}
\hline Extract & Wavelength (nm) & $\begin{array}{l}\text { No. of } \\
\text { peaks }\end{array}$ & Rf values & Percentage peaks area \\
\hline \multirow[t]{2}{*}{ A } & 254 & 14 & $\begin{array}{l}0.05,0.12,0.18,0.27,0.30,0.38,0.44,0.47 \\
0.52,0.53,0.60,0.70,0.77,0.92\end{array}$ & $\begin{array}{l}0.59,4.48,16.14,1.13,3.66,3.80,3.00,9.54,4.15 \\
4.37,12.92,2.46,33.31,0.46\end{array}$ \\
\hline & 366 & 13 & $\begin{array}{l}0.12,0.18,0.39,0.40,0.47,0.52,0.58,0.62 \\
0.68,0.75,0.80,0.92\end{array}$ & $\begin{array}{l}2.68,38.56,3.54,5.55,10.82,2.65,1.14,16.60,4.07 \\
9.32,3.03,1.05\end{array}$ \\
\hline \multirow[t]{2}{*}{ B1 } & 254 & 15 & $\begin{array}{l}0.18,0.30,0.36,0.37,0.40,0.51,0.59,0.63 \\
0.68,0.71,0.74,0.80,0.83,0.90,0.96\end{array}$ & $\begin{array}{l}14.16,0.87,2.24,2.20,1.62,4.55,2.35,7.14,9.85 \\
2.17,30.68,2.03,5.26,2.94,11.85\end{array}$ \\
\hline & 366 & 9 & $0.18,0.51,0.62,0.68,0.71,0.74,0.80,0.83,0.96$ & $\begin{array}{l}11.87,4.10,5.43,10.50,2.96,19.47,8.53,11.79 \\
25.35\end{array}$ \\
\hline \multirow[t]{2}{*}{ B2 } & 254 & 15 & $\begin{array}{l}0.19,0.27,0.29,0.36,0.41,0.52,0.59,0.63 \\
0.68,0.74,0.80,0.83,0.87,0.90,0.96\end{array}$ & $\begin{array}{l}11.97,1.23,1.47,2.01,3.42,6.48,7.34,8.96,11.33 \\
2.48,6.62,0.48,3.74,1.96\end{array}$ \\
\hline & 366 & 11 & $\begin{array}{l}0.18,0.38,0.41,0.51,0.61,0.67,0.74,0.80 \\
0.83,0.87,0.96\end{array}$ & $\begin{array}{l}11.24,1.08,2.40,4.02,10.66,10.90,12.94,9.68 \\
14.21,0.30,22.57\end{array}$ \\
\hline \multirow[t]{2}{*}{ B3 } & 254 & 8 & $0.17,0.18,0.60,0.61,0.66,0.70,0.74,0.78$ & $4.91,8.16,21.99,6.16,19.5,14.80,14.50,9.96$ \\
\hline & 366 & 5 & $0.18,0.78,0.82,0.92,0.96$ & $18.60,12.90,17.70,4.47,46.33$ \\
\hline \multirow[t]{2}{*}{$\mathrm{C}$} & 254 & 16 & $\begin{array}{l}0.06,0.08,0.16,0.19,0.28,0.30,0.36,0.40 \\
0.52,0.59,0.62,0.68,0.73,0.82,0.83,0.96\end{array}$ & $\begin{array}{l}1.79,4.17,3.60,5.37,5.33,4.06,1.34,5.44,1.94, \\
9.88,7.99,16.49,27.23,1.80,2.65,0.92\end{array}$ \\
\hline & 366 & 7 & $0.19,9.61,0.66,0.74,0.79,0.83,0.97$ & $10.79,10.12,5.08,7.07,4.79,8.83,53.31$ \\
\hline \multirow[t]{2}{*}{ D1 } & 254 & 12 & $\begin{array}{l}0.06,0.15,0.20,0.28,0.37,0.37,0.40,0.54 \\
0.61,0.73,0.82,0.87,0.95\end{array}$ & $\begin{array}{l}1.46,0.93,24.29,11.06,9.18,8.72,1.49,21.76,11.91 \text {, } \\
0.89,2.55,5.77\end{array}$ \\
\hline & 366 & 11 & $\begin{array}{l}0.06,0.20,0.37,0.39,0.61,0.66,0.73,0.77 \\
0.87,0.96,0.97\end{array}$ & $\begin{array}{l}4.77,16.12,3.49,9.02,46.10,3.14,2.34,4.88,1.69 \\
4.49,3.95\end{array}$ \\
\hline \multirow[t]{2}{*}{ D2 } & 254 & 7 & $0.09,0.15,0.17,0.20,0.28,0.58,0.74$ & $4.73,4.21,11.13,17.91,5.00,37.70,19.31$ \\
\hline & 366 & 6 & $0.17,0.20,0.58,0.610 .74,0.96$ & $5.26,18.31,13.94,30.08,20.67,11.74$ \\
\hline \multirow[t]{2}{*}{ E } & 254 & 13 & $\begin{array}{l}0.03,0.09,0.13,0.21,0.29,0.37,0.44,0.54 \\
0.59,0.68,0.74,0.85,0.94\end{array}$ & $\begin{array}{l}2.37,1.55,4.31,5.88,13.49,13.75,5.98,5.74,31.37 \\
2.65,6.29,1.95,4.67\end{array}$ \\
\hline & 366 & 9 & $0.03,0.09,0.12,0.20,0.62,0.66,0.74,0.77,0.96$ & $1.06,1.27,5.62,5.37,52.12,8.97,5.87,10.81,8.90$ \\
\hline \multirow[t]{2}{*}{$\mathrm{p}$} & 254 & 3 & $0.30,0.59,0.63$ & $14.79,29.80,55.42$ \\
\hline & 366 & 3 & $0.29,0.59,0.63$ & $1.16,44.12,54.72$ \\
\hline
\end{tabular}

A - A method, B - B methods (3 fraction), C - C method, D - D methods (2 fraction), E - E method, and piperine (control), (254 and 366 ) wavelength at 254 and 366 nm. TLC: Thin layer chromatography

Table 3: TLC profiles using toluene:acetone:ethanol:25\% ammonia eluent (20:20:3:1)

\begin{tabular}{|c|c|c|c|c|}
\hline Extract & Wavelength (nm) & $\begin{array}{l}\text { No. of } \\
\text { peaks }\end{array}$ & Rf values & Percentage peaks area \\
\hline \multirow[t]{2}{*}{ A } & 254 & 10 & $\begin{array}{l}0.08,0.26,0.31,0.39,0.52,0.68,0.71,0.74,0.88 \\
0.97\end{array}$ & $\begin{array}{l}1.53,1.04,2.73,1.37,2.97,2.39,15.12,30.82,17.36 \text {, } \\
1.68\end{array}$ \\
\hline & 366 & 8 & $0.08,0.26,0.31,0.52,0.71,0.82,0.88,0.96$ & $1.91,1.19,9.09,2.75,64.23,14.29,6.38,0.17$ \\
\hline \multirow[t]{2}{*}{ B1 } & 254 & 9 & $0.06,0.28,0.30,0.53,0.68,0.70,0.78,0.90,0.98$ & $1.21,5.17,7.98,1.69,30.70,19.66,15.50,14.92,3.18$ \\
\hline & 366 & 8 & $0.13,0.24,0.29,0.52,0.68,0.89,0.94,0.97$ & $1.26,1.26,10.74,4.13,7517,3.45,1.95,2.05$ \\
\hline \multirow[t]{2}{*}{ B2 } & 254 & 10 & $0.03,0.25,0.52,0.57,0.66,0.69,0.76,0.89,0.97$ & $\begin{array}{l}0.44,5.56,2.44,2.06,30.65,17.13,8.38,12.55 \\
15.77,5.02\end{array}$ \\
\hline & 366 & 10 & $\begin{array}{l}0.03,0.12,0.25,0.51,0.67,0.69,0,80,0.88,0.93, \\
0.97\end{array}$ & $\begin{array}{l}0.40,0.72,10.26,5.56,45.03,26.99,3.88,2.65,1.10 \text {, } \\
3.39\end{array}$ \\
\hline \multirow[t]{2}{*}{ B3 } & 254 & 10 & $\begin{array}{l}0.03,0.09,0.12,0.33,0.43,0.57,0.66,0.69,0.74 \\
0.98\end{array}$ & $\begin{array}{l}0.91,0.85,1.61,6.59,2.31,4.34,30.94,24.49,21.65 \text {, } \\
6.32\end{array}$ \\
\hline & 366 & 9 & $0.03,0.33,0.51,0.57,0.66,0.69,0.81,0.87,0.97$ & $1.01,14.14,2.63,2.19,44.12,22.64,3.63,1.90,7.72$ \\
\hline \multirow[t]{2}{*}{$\mathrm{C}$} & 254 & 8 & $0.34,0.42,0.44,0.64,0.69,0.72,0.88,0.97$ & $0.83,0.66,0.27,29.08,23.87,29.10,12.82,3.39$ \\
\hline & 366 & 7 & $0.4,0.43,0.51,0.65,0.69,0.87,0.97$ & $3.79,1.09,38.29,43.87,7.82,4.42$ \\
\hline \multirow[t]{2}{*}{ D1 } & 254 & 14 & $\begin{array}{l}0.07,0.11,0.30,0.42,0.44,0.50,0.61,0.64,0.68 \\
0.76,0.81,0.86,0.91,0.96\end{array}$ & $\begin{array}{l}4.75,2.50,3.19,0.25,0.17,3.61,5.78,9.39,15.59 \\
27.09,11.16,5.50,5.21,5.81\end{array}$ \\
\hline & 366 & 14 & $\begin{array}{l}0.06,0.12,0.19,0.30,0.39,0.43,0.50,0.61,0.64 \\
0.68,0.75,0.81,0.86,0.97\end{array}$ & $\begin{array}{l}0.43,1.24,0.85,14.48,0.38,1.53,3.10,6.78,6.32, \\
16.62,16.99,20.99,7.87,2.42\end{array}$ \\
\hline \multirow[t]{2}{*}{ D2 } & 254 & 11 & $\begin{array}{l}0.44,0.48,0.50,0.56,0.64,0.69,0.75,0.80,0.88 \\
0.93,0.96\end{array}$ & $\begin{array}{l}0.59,3.04,1.55,3.61,23.81,40.33,13.15,6.04,3.16 \text {, } \\
3.11,1.62\end{array}$ \\
\hline & 366 & 8 & $0.38,0.48,0.56,0.64,0.68,0.80,0.88,0.93$ & $4.52,2.02,6.24,24.60,44.55,12.69,3.98,1.41$ \\
\hline \multirow[t]{2}{*}{$\mathrm{E}$} & 254 & 8 & $0.34,0.40,0.49,0.72,0.75,0.85,0.92,0.96$ & $0.42,1.78,1.35,31.66,31.85,21.95,5.35,5.63$ \\
\hline & 366 & 4 & $0.69,0.75,0.80,0.96$ & $32.52,14.00,48.15,5.33$ \\
\hline \multirow[t]{2}{*}{$\mathrm{P}$} & 254 & 3 & $0.71,0.86,0.93$ & $2.26,88.63,9.10$ \\
\hline & 366 & 3 & $0.66,0.86,0.95$ & $1.80,96.62,1.58$ \\
\hline
\end{tabular}

A - A method, B - B methods (3 fraction), C - C method, D - D methods (2 fraction), E - E method, (P) (piperine) control, (254 and 366) wavelength at 254 and $366 \mathrm{~nm}$. TLC: Thin layer chromatography

\section{Calculation of total alkaloid}

Calculation of total alkaloid used an indirect way because that measured is bismuth bounded on the alkaloids, instead of alkaloid compound. The Dragendorff reagent additions caused the formation of precipitate complexes between alkaloids and bismuth compound. The bismuth is irrespective of its ties with the alkaloid with the 


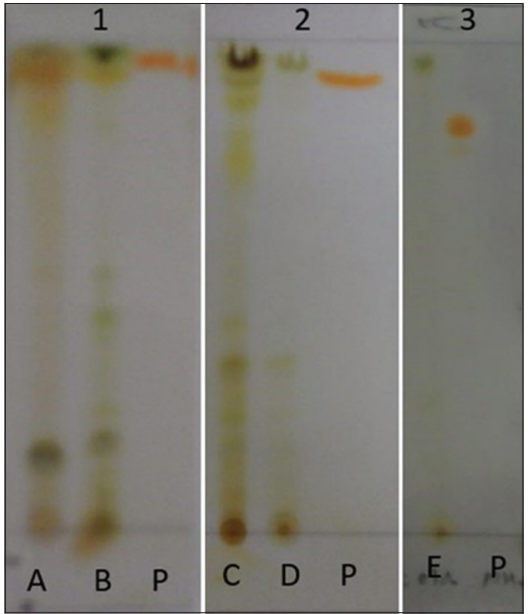

Fig. 2: Identification alkaloid using Dragendorff spray reagent,

(1) using dichloromethane:methanol eluent (95:5),

(2) using dichloromethane:methanol eluent (97:3),

(3) using toluene:acetone:ethanol:25\% ammonia (20:20:3:1),

(A) Method A, (B) Method B, (C) Method C, (D) Method D, (E) Method E, and piperine (control)

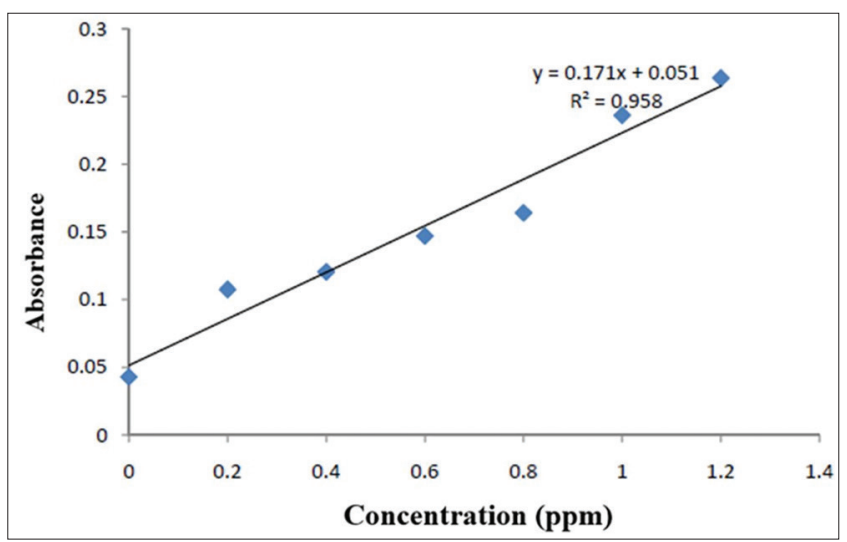

Fig. 3: Calibration curve and linear regression of piperine as a standard

Table 4: Absorbance of total alkaloid test results

\begin{tabular}{lll}
\hline Concentration (ppm) & Absorbance & $\begin{array}{l}\text { Linear regression } \\
\text { formula }\end{array}$ \\
\hline DCM fraction (117 ppm) & 0.1990 & $\begin{array}{l}\mathrm{Y}=0.171 \mathrm{X}+0.051 \\
\text { with } \mathrm{r}=0.958\end{array}$ \\
Piperine (standard) & & \\
0 & 0.0430 & \\
0.2 & 0.1075 & \\
0.4 & 0.1205 & \\
0.6 & 0.1470 & \\
0.8 & 0.1640 & \\
1.0 & 0.2360 & \\
1.2 & 0.2635 & \\
\hline
\end{tabular}

DCM: Dichloromethane

addition of sodium sulfide. The addition of thiourea in the medium led to the formation of nitric acid complex Bi $\left[\mathrm{CS}\left(\mathrm{NH}_{2}\right)_{3}\right]\left(\mathrm{NO}_{3}\right)_{3}$ in the form of a yellow precipitate. The precipitate measured with visible light $435 \mathrm{~nm}$ [22].

The selected standard as a Piperine is an alkaloid compound derived from the family of Piperaceae which is expected to describe the alkaloids contained in P. pellucida. The piperine as a standard was made in several concentrations (including $0,0.2,0.4,0.6,0.8,1$, and $1.2 \mathrm{ppm}$ ), and the absorbances were measured using spectrophotometer at wavelength $435 \mathrm{~nm}$ (Table 4 and Fig. 3). Total alkaloids in DCM fraction amounted to $29.59 \mathrm{mg} / \mathrm{g}$ piperine.

\section{CONCLUSION}

Based on the results of the study of the extraction method development with the alkaloid enrichment purposes obtained TLC profiles of different uses three kinds of eluent combinations of separating spots of the compound contained in each extract, these results will be the basis for isolation of alkaloids. While for identification still needs to be done using the special way that can be detected alkaloid compounds in the plants.

\section{ACKNOWLEDGMENTS}

This work was supported by Directorate Research and Humanity Engagement (DRPM), Universitas Indonesia via grant "Hibah PUPT 2015." Many thanks to Faculty of Pharmacy, Universitas Indonesia for offering infrastructural facilities.

\section{REFERENCES}

1. Heyne K. The Useful Indonesian Plants: Research and Development Agency. Jakarta, Indonesia: Ministry of Forestry, Indonesia; 2007. p. $1-462$.

2. Chandel HS, Pathak AK, Tailang M. Standardization of some herbal antidiabetic drugs in polyherbal formulation. Pharmacognosy Res 2011;3(1):49-56

3. Hamzah RU, Odetola AA, Erukainure OL, Oyagbemi AA. Peperomia pellucida in diets modulates hyperglyceamia, oxidative stress and dyslipidemia in diabetic rats. J Acute Dis 2012;1(2):135-40.

4. Tarigan IM, Bahri S, Saragih A. Antihyperuricemia activity of Suruhan (Peperomia pellucida L. Kunth) herb ethanol extract on Mus musculus male. J Pharm Pharmacol 2012;1(1):37-43.

5. Arrigoni-Blank FM, Dmitrieva EG, Franzotti EM, Antoniolli AR, Andrade MR, Marchioro M. Anti-inflammatory and analgesic activity of Peperomia pellucida (L.) HBK (Piperaceae). J Ethnopharmacol 2004;91(2-3):215-8.

6. Saputri FC, Mun'im A, Lukmanto D, Aisyah SN, Rinandy JS. Inhibiton of angiotensin converting enzyme (ACE) activity by some indonesia edible plants. Int J Pharm Sci Res 2015;6(3):1054-9.

7. Kurniawan A, Saputri F, Ahmad I, Mun'im A. Isolation of angiotensin converting enzyme (ACE) inhibitory activity quercetin from Peperomia pellucida. Int J PharmTech Res 2016;9(7):115-21.

8. Majumder P. Evaluation of taxo-chemical standardization and quality control parameters of Peperomia Pellucida (Family: Piperaceae): A multi valuable medicinal herb. J Pharm Sci Innov 2012;1(6):7-12.

9. Majumder P, Abraham P, Satya V. Ethno-medicinal, phytochemical, and pharmacological review of an amazing medicinal herb Peperomia pellucida (L.) HBK. Res J Pharm Biol Chem Sci 2011;2(4):358-64

10. Xu S, Li N, Ning MM, Zhou $\mathrm{CH}$, Yang QR, Wang MW. Bioactive compounds from Peperomia pellucida. J Nat Prod 2006;69(2):247-50.

11. Bayma JD, Arruda MS, Müller AH, Arruda AC, Canto WC. A dimeric ArC2 compound from Peperomia pellucida. Phytochemistry 2000;55(7):779-82.

12. Susilawati Y, Nugraha R, Muhtadi A, Soetardjo S, Supratman U. (S)-2-Methyl-2-(4-methylpent-3-enyl)-6-(propan-2-ylidene)3,4,6,7-tetrahydropyrano[4,3-g]chromen-9(2H)-one. Molbank 2015;2015(2):1-6.

13. Khan MR, Omoloso AD. Antibacterial activity of Hygrophila stricta and Peperomia pellucida. Fitoterapia 2002;73:251-4

14. Mensah JK, Okoli RI, Turay AA. Phytochemical analysis of medicinal plants used for the management of hypertension by esan people of edo state, Nigeria. Ethnobot Leafl 2009;13(12):73-87.

15. Leena PK, Annam C. Preliminary phytechemical screening and in-vitro cytotoxicity activity of Peperomia pellucida linn. Int J Compr Pharm 2013;4(8):1-4

16. Majumder P, Majumder S. Preparation and characterization of some herball ointment formulations with evaluation of antimicrobial property. Indian J Res Pharm Biotetechnol 2013;1:385-90.

17. Igwe OU, Mgbemena NM. A chemical investigation and antibacterial activity of the leaves of Peperomia pellucida L. HBK (Piperaceae). Asian J Chem Pharm Res 2014;2(1):78-86.

18. Gini TG, Jothi GJ. Preliminary phytochemical screening for active compounds in the whole plant extract of Peperomia pellucida (Linn.) 
HBK (Piperaceae) and Marsilea quadrifolia Linn. (Marsileaceae). Int J Pharmacogn Phytochem Res 2013;5(3):200-14.

19. Tiong SH, Looi CY, Hazni H, Arya A, Paydar M, Wong WF, et al. Antidiabetic and antioxidant properties of alkaloids from Catharanthus roseus (L.) G. Don. Molecules 2013;18(8):9770-84.

20. Lebrini M, Robert F, Roos C. Alkaloids extract from Palicourea guianensis plant as corrosion inhibitor for $\mathrm{C} 38$ steel in $1 \mathrm{M}$ hydrochloric acid medium. Int J Electrochem Sci 2011;6:847-59.

21. Wagner H, Bladt S. In: Rickl V, editor. Plant Drug Analysis: A Thin Layer Chromatography Atlas. $2^{\text {nd }}$ ed., Vol. 18. New York, US: Springer; 1995.

22. Rashid MH, Biswas S, Abdullah-Al-Mamun M, Huque A, Bhuiyan JR. Phytochemical screening and analgesic, anti-bacterial and cytotoxic activity evaluation of ethanol extract of Pithcellobium dulce (Roxb.) benth leaf. Asian J Pharm Clin Res 2015;8(2):451-7.

23. Hemmalakshmi S, Priyanga S, Devaki K. Phytochemical screening and HPTLC fingerprinting analysis of ethanolic extract of Erythrina variegata L. flowers. Int J Pharm Pharm Sci 2016;8(3):210-7.

24. Sutar RC, Kasture SB, Kalaichelvan VK. Preliminary phytochemical screening and high performance thin layer chromatography fingerprint profile of leaf extracts of Holoptelea integrifolia (Roxb.) planch. Asian J Pharm Clin Res 2014;7(4):94-7.

25. Sharanappa R, Vidyasagar GM. Plant profile, phytochemistry and pharmacology of Argemone mexicana Linn. A review. Int J Pharm Pharm Sci 2014;6(7):45-53.

26. Sreevidya N, Mehrotra S. Spectrophotometric method for estimation of alkaloids precipitable with dragendorff's reagent in plant materials. J AOAC Int 2003;86(6):1124-7. 